\title{
Variation in cell-specific rates of leucine and thymidine incorporation by marine bacteria with high and with low nucleic acid content off the Oregon coast
}

\author{
K. Longnecker*, B. F. Sherr, E. B. Sherr \\ College of Oceanic and Atmospheric Sciences, Oregon State University, 104 COAS Administration Building, Corvallis, \\ Oregon 97331-5503, USA
}

\begin{abstract}
The balance between rates of protein synthesis (measured by incorporation of radioactively labeled leucine) and rates of DNA synthesis (measured by incorporation of radioactively labeled thymidine) has been used to evaluate growth state in marine bacterioplankton. Our objective was to determine if variability in leucine and thymidine incorporation could further elucidate ecological differences in the role of high nucleic acid (HNA) and low nucleic acid (LNA) cells in marine ecosystems. We report here the first data set in which cell-specific rates of leucine and thymidine incorporation have been compared for HNA and LNA bacterial cells in the open ocean. In general, HNA cells had higher cell-specific incorporation rates of both leucine and thymidine, and had higher leucine:thymidine (Leu:TdR) incorporation ratios than LNA cells. The higher Leu:TdR ratios for HNA cells suggest that increases in the ratio may be associated with increased metabolic activity by marine bacterioplankton. Leu:TdR incorporation ratios were significantly positively correlated to temperature, but not to chlorophyll a concentrations or phytoplankton biomass calculated from specific carbon:chlorophyll a ratios, indicating that in this region temperature had a greater effect on bacterial growth state than did substrate supply. The proportion of total heterotrophic bacterial activity attributable to LNA cells was significantly greater at slope and basin stations compared to the mesotrophic shelf station. Finally, the difference in incorporation rates between HNA and LNA cells was greater for protein synthesis than for DNA synthesis.
\end{abstract}

KEY WORDS: Marine bacterioplankton · Metabolic activity · Leucine incorporation · Thymidine incorporation Resale or republication not permitted without written consent of the publisher

\section{INTRODUCTION}

Marine heterotrophic bacterioplankton play a vital role in global carbon cycling (Legendre \& Fèvre 1995, Ducklow 1999). However, variability in metabolic activity by bacterioplankton (Cottrell \& Kirchman 2003, Smith \& del Giorgio 2003) complicates elucidation of their role in biogeochemical cycling. Both variability in the phylogenetic diversity and proportional abundance of metabolically active cells (Malmstrom et al. 2004, Herndl et al. 2005), and variability in cell-specific activity of bacterioplankton across ecosystems
(Lebaron et al. 2001, Longnecker et al. 2005) have been observed.

The balance between leucine and thymidine incorporation indicates relative rates of biomass production compared to rates of cell replication. Growth is considered balanced when all constituents of a cell increase at the same proportional rate over a given time interval (Neidhardt et al. 1990). Therefore, when rates of protein synthesis and DNA synthesis are uncoupled, growth is unbalanced (Chin-Leo \& Kirchman 1990). Variability in the ratio of leucine to thymidine incorporation (Leu:TdR ratio) has been interpreted as a change 
in the growth state of marine bacterioplankton (ChinLeo \& Kirchman 1990, Shiah \& Ducklow 1997, Pomroy \& Joint 1999). Complicating interpretation of Leu:TdR ratios is their variability over temporal and spatial scales (Li et al. 1993, Gasol et al. 1998, Pomroy \& Joint 1999, Ducklow et al. 2001a,b). Furthermore, both substrate supply (Chin-Leo \& Kirchman 1990, Kirchman 1990) and temperature (Tibbles 1996, Shiah \& Ducklow 1997) can affect in situ Leu:TdR ratios. Temperature is particularly difficult, as Tibbles (1996) observed positive correlations between temperature and Leu:TdR ratios, while Shiah \& Ducklow (1997) observed the opposite, with lower Leu:TdR ratios measured at higher temperatures in both temperature manipulation experiments and in situ. Thus, there is a lack of clear consensus on the meaning of Leu:TdR ratios and what causes spatial variability in them (Ducklow 2000).

Flow cytometric enumeration of marine bacterioplankton has shown that the cells fall into a minimum of 2 distinct clusters based on nucleic acid staining: bacteria with higher nucleic acid content (HNA) and bacteria with lower nucleic acid content (LNA) (Li 1995, Jellett et al. 1996, Marie et al. 1997, Gasol et al. 1999, Troussellier et al. 1999, Gasol \& del Giorgio 2000, Button \& Robertson 2001, Lebaron et al. 2001). Flow cytometric sorting of heterotrophic bacteria incubated with radioactively labeled metabolic precursors has provided valuable insights into variability in cell-specific activity of HNA and LNA cells (Zubkov et al. 2001, Lebaron et al. 2002, Servais et al. 2003). Although the distinction between HNA and LNA cells is based on nucleic acid content, there have been no studies investigating variability in DNA synthesis between them.

The primary goal of the present study was to compare leucine and thymidine incorporation rates by HNA and LNA sub-populations of marine bacterioplankton. These data were collected in order to improve our understanding of ecological differences between HNA and LNA cells in marine ecosystems, and to characterize differences in growth state between HNA and LNA cells. The range of trophic conditions present across the Oregon upwelling system (Chavez et al. 2002, Huyer et al. 2002, Peterson et al. 2002) allowed us to assess variability in cell-specific activity and Leu:TdR incorporation ratios under different ecological conditions.

\section{MATERIALS AND METHODS}

Sample collection and experimental setup. Samples were collected in September 2004 at the end of the upwelling season. We chose 3 stations in different hydrographic regimes along a transect line extending westward from Heceta Head, Oregon: a shelf station,
$5 \mathrm{~km}$ from shore, bottom depth $54 \mathrm{~m}\left(\mathrm{HH} 1,44^{\circ} \mathrm{N}\right.$ $\left.124.2^{\circ} \mathrm{W}\right)$, a slope station, $53 \mathrm{~km}$ from shore, bottom depth $112 \mathrm{~m}\left(\mathrm{HH} 4,44^{\circ} \mathrm{N} 124.8^{\circ} \mathrm{W}\right)$, and a basin station above the abyssal plain, $237 \mathrm{~km}$ from shore, bottom depth $2940 \mathrm{~m}$ (HH127, 44 ${ }^{\circ} \mathrm{N} 127.1^{\circ} \mathrm{W}$ ) (Fig. 1).

Environmental parameters. At each station, water was collected in 3 separate hydrocasts using General Oceanics 51 Niskin bottles mounted on a rosette equipped with a SeaBird SBE 911+ CTD and a SeaTech fluorometer. Chlorophyll a (chl a) concentration was used as a proxy for phytoplankton biomass. Discrete water samples were filtered through GF/F filters and kept frozen at $-80^{\circ} \mathrm{C}$ for up to 1 mo before processing; $90 \%$ high-performance liquid chromatography (HPLC) grade acetone was added to the filters and allowed to extract overnight at $-20^{\circ} \mathrm{C}$. Chl a concentrations were determined using a Turner Designs 10-AU fluorometer (Strickland \& Parsons 1972). Samples for nutrient analysis were stored frozen $\left(-20^{\circ} \mathrm{C}\right)$ in $60 \mathrm{ml}$ high-density polyethylene bottles. The analyses for phosphate, nitrate plus nitrite $(\mathrm{N}+\mathrm{N})$, nitrite and silicic acid (silicate) were performed using a hybrid Technicon AutoAnalyzerII and Alpkem RFA300 system following protocols modified from Gordon et al. (1994).

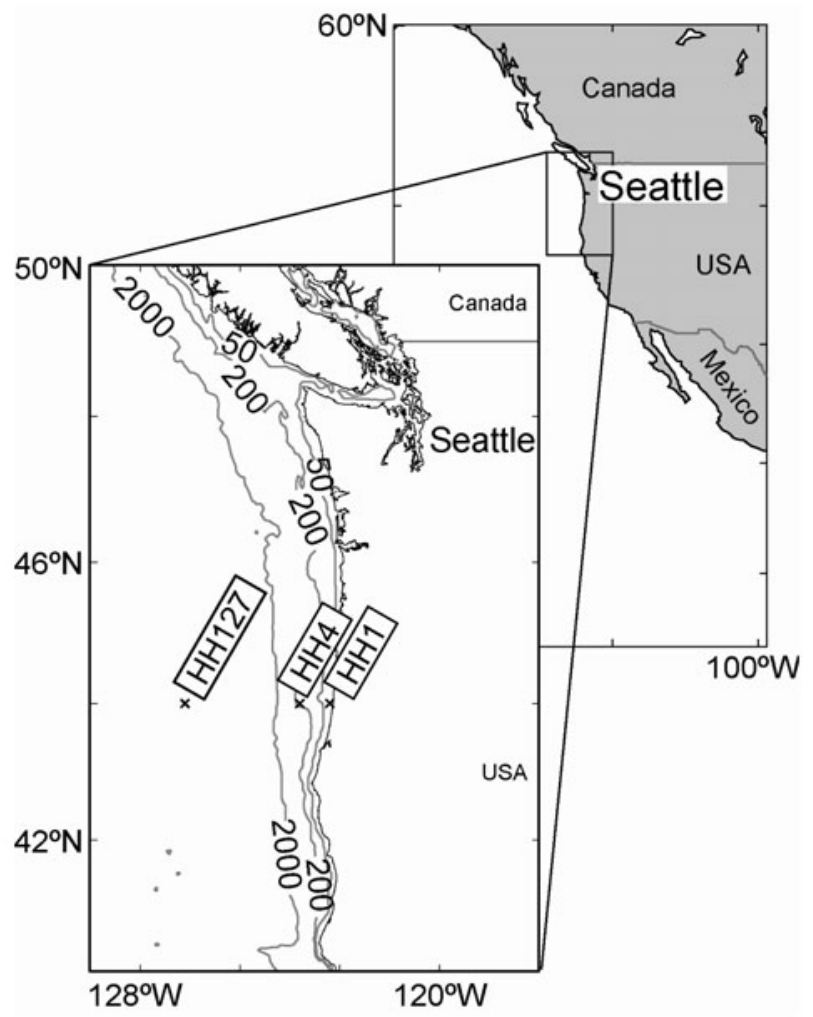

Fig. 1. Sampling area. Contour lines in inset represent 50, 200 and $2000 \mathrm{~m}$ isobaths. Multiple casts were conducted at each of the 3 stations: a shelf station (HH1), a slope station (HH4), and a basin station above the abyssal plain (HH127) 
Nitrate concentrations were determined by subtracting nitrite from the $\mathrm{N}+\mathrm{N}$ value. The estimated precision for each element is $\mathrm{PO}_{4}, \pm 0.008 \mu \mathrm{M}, \mathrm{N}+\mathrm{N}, \pm 0.15 \mu \mathrm{M}$, $\mathrm{NO}_{2}, \pm 0.01 \mu \mathrm{M}$, and silicic acid, $\pm 0.3 \mu \mathrm{M}$.

Volumetric leucine and thymidine incorporation by bacteria in whole seawater. Incorporation rates of ${ }^{3} \mathrm{H}$-leucine and ${ }^{3} \mathrm{H}$-thymidine by bacterioplankton present in whole seawater samples were assayed following the protocol of Smith \& Azam (1992). Four $1.5 \mathrm{ml}$ aliquots of each water sample were pipetted into copolymer Fisher Porex microcentrifuge tubes containing either ${ }^{3} \mathrm{H}$-leucine (Perkin Elmer Life Science Products, specific activity $173 \mathrm{Ci} \mathrm{mmol}^{-1}$ ) to yield 20 nM final concentration, or ${ }^{3} \mathrm{H}$-thymidine (Perkin Elmer Life Science Products, specific activity 80.2 Ci $\mathrm{mmol}^{-1}$ ) to yield $10 \mathrm{nM}$ final concentration. These concentrations have been previously shown to be saturating amounts for bacterial incorporation rates in the Oregon upwelling system (Sherr et al. 2001). Of the 4 aliquots, 1 served as a killed control, with 5\% (final concentration) of trichloroacetic acid (TCA) being immediately added to the tube. The aliquots were incubated for $1 \mathrm{~h}$ in the dark at in situ water temperature $\left(5.5\right.$ to $\left.18.7^{\circ} \mathrm{C}\right)$. The samples were then killed with $5 \%$ TCA (final concentration), and stored frozen at $-20^{\circ} \mathrm{C}$. Samples were returned to shore and processed no more than 3 wk after the sampling date. Prior experiments with radioactively labeled samples frozen for up to 1 mo showed no difference in leucine incorporation rates compared to unfrozen samples processed immediately (data not shown). Activity was determined using a Wallac 1141 liquid scintillation counter (LSC). The activity of the killed control was subtracted from values for the 3 live aliquots.

Flow cytometric analysis of bacteria. A BectonDickinson FACSCalibur flow cytometer was used for all cell enumeration and cell sorting. For enumeration, $3 \mathrm{ml}$ sample aliquots were fixed with $0.2 \% \mathrm{w} / \mathrm{v}$ paraformaldehyde (final concentration), stored in the dark for at least $10 \mathrm{~min}$ at room temperature to harden cells, frozen in liquid nitrogen, and stored at $-80^{\circ} \mathrm{C}$ until sample processing on shore. To determine rates of cell-specific leucine or thymidine incorporation, separate $3 \mathrm{ml}$ water samples were incubated immediately after collection with $40 \mathrm{nM}$ of ${ }^{3} \mathrm{H}$-leucine (specific activity $170 \mathrm{Ci} \mathrm{mmol}{ }^{-1}$ ) or $20 \mathrm{nM}$ of ${ }^{3} \mathrm{H}$-thymidine (specific activity $80.2 \mathrm{Ci} \mathrm{mmol}^{-1}$ ) in the dark for $1 \mathrm{~h}$ at the in situ water temperature. These concentrations of leucine and thymidine were 2 -fold higher than the saturating concentrations used for volumetric bacterial activity measurements, to ensure sufficient labeling of bacterial cells. Samples for radioactively labeled sorting were then fixed and stored as described above.

After thawing, aliquots of samples collected for determination of bacterial abundance and cell-specific nucleic acid content were stained with a $1 \times$ working stock of SYBR Green I (Molecular Probes) and $25 \mathrm{mM}$ potassium citrate for $15 \mathrm{~min}$ following a protocol modified from Marie et al. (1997). The abundance of cells was determined by calculating the flow rate with known concentrations of $1 \mu \mathrm{m}$ fluorescent microspheres (Polysciences). Regions were established on cytogram plots of side scatter versus green fluorescence, and adjusted for each sample, to define bacterial cells with high nucleic acid content (HNA) and low nucleic acid content (LNA) (Fig. 2). In addition to abundance, fluorescence data were obtained for each sample. The data for side scatter (a proxy for cell size) and green fluorescence were normalized to the microspheres' fluorescence to minimize between-sample variability.

All sorts were run on low flow using the 'single cell option' of the Becton-Dickinson Cell Quest software. Tests in our laboratory (Longnecker et al. 2005) and recently published data (Ferrari et al. 2004) indicate that flow cytometry can be used to sort cells with high purity if sort rates are below 300 cells $\mathrm{s}^{-1}$. In situ abundance of bacteria encountered in our samples resulted in sort rates averaging less than about 170 cells s${ }^{-1}$. Prior to sorting, aliquots of each thawed sample were incubated in the dark for 15 min with a $1 \times$ working stock of SYBR Green I. Bacterial cells were sorted into HNA and LNA cells onto $25 \mathrm{~mm}, 0.2 \mu \mathrm{m}$ cellulose acetate membranes using the Becton-Dickinson cell concentrator unit attached to the flow cytometer's sort line. A total of $1.0 \times 10^{5}$ SYBR-stained cells were sorted for each region. Sorts lasted from 10 to $75 \mathrm{~min}$; during longer sorts we placed a freshly

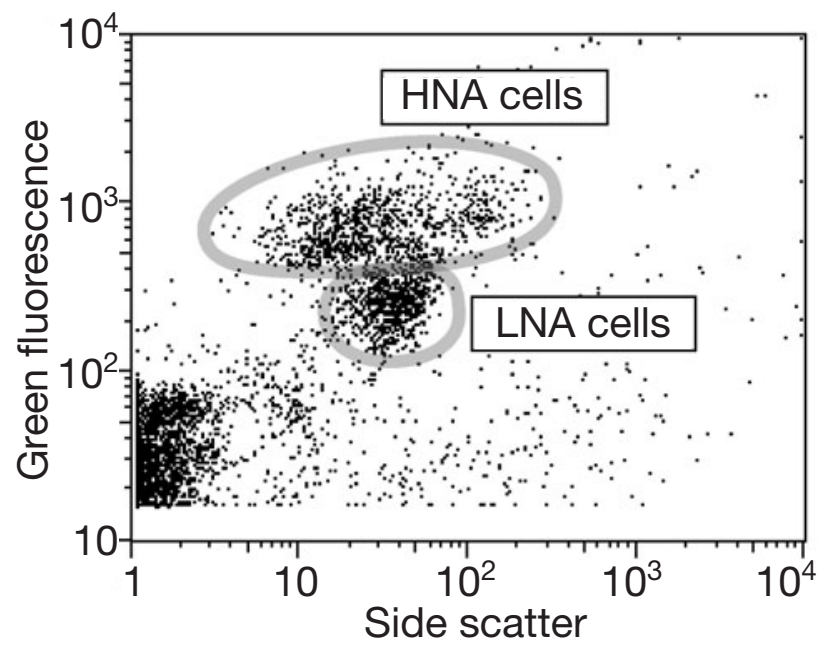

Fig. 2. Cytograms indicating sort regions for high nucleic acid (HNA) and low nucleic acid (LNA) cells defined by plots of side scatter versus green fluorescence. Sort regions were moved for each sample as necessary 
stained aliquot of the sample on the flow cytometer every $15 \mathrm{~min}$.

After collection of the target number of cells, the membrane filter was removed from the cell concentrator unit, transferred to a filter manifold, and processed following the method of Kirchman (1993), which has been shown to result in values of substrate incorporation similar to the centrifugation method of Smith \& Azam (1992). The filter was washed twice with cold $5 \%$ TCA and twice with cold $80 \%$ ethanol, then folded into a $7 \mathrm{ml}$ scintillation vial and allowed to dry. Ethyl acetate $(0.5 \mathrm{ml})$ was added to the scintillation vial to dissolve the filter, followed by $4 \mathrm{ml}$ of scintillation cocktail (Ultima Gold LLT, PerkinElmer). The samples were allowed to sit for $2 \mathrm{~d}$ before counting on a Wallac 1141 LSC. For each sample, the dpm of the TCA-killed vial that had served as a control for the whole seawater samples was subtracted from the dpm of the cell sorts for that sample. Cell-specific rates of leucine or thymidine incorporation were obtained by dividing the molar incorporation rate determined for each filter by the number of cells sorted for that sample. Leucine to thymidine incorporation (Leu:TdR) ratios were calculated separately for HNA and LNA cells, i.e. HNA Leu:TdR ratios were based on cell-specific HNA leucine incorporation rates divided by cell-specific HNA thymidine incorporation rates.

In addition to estimation of cell-specific rates, volumetric incorporation rate was calculated for each sorted group by multiplying the abundance of cells within each sorted region by the average cell-specific incorporation rate for that group. The calculated volumetric incorporation rates based on cell sorting are thus distinct from whole seawater volumetric incorporation rates obtained empirically from non-sorted samples incubated with radioactively labeled leucine or thymidine.
Statistical analysis. Statistical analyses were conducted in Matlab v7.0.1 (The Mathworks). Analyses performed included Pearson's correlation coefficient, Student's $t$-test with post-hoc Bonferroni correction, 1-way ANOVAs, Tukey-Kramer multiple comparison tests, and Model II regressions. Unless otherwise noted, data were square-root transformed prior to analysis to reduce skewness and kurtosis.

\section{RESULTS}

\section{Environmental parameters}

The 3 sampling stations were characterized by differences in both biological and physical parameters. Surface water temperatures were highest at the basin station, with lower values at the shelf and slope stations (Table 1). Nutrient concentrations increased with increasing depth at all 3 stations, with the lowest values measured at the surface of the basin station. Chl a concentrations were highest at the surface of the shelf station. Chl a values integrated through the upper $50 \mathrm{~m}$ of the water column were significantly higher at the shelf station $(82.6 \mathrm{mg}$

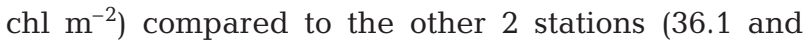
$26.3 \mathrm{mg} \mathrm{chl} \mathrm{m}{ }^{-2}$, for the slope and basin station respectively; 1 -way ANOVA $\mathrm{p}<<0.0001$, followed by multiple comparisons with Tukey-Kramer correction). The abundance of non-fluorescent bacterial cells (assumed to be heterotrophs) decreased with increasing depth at the shelf station, but had mid-depth maxima at the slope and basin stations (Table 1). The mid-depth maxima in the abundance of heterotrophic prokaryotes was co-located with mid-depth maxima in chl a (Table 1). The percentage of HNA cells was significantly higher at the shelf station compared to

Table 1. Environmental parameters measured concurrently with sample collection, summarized for each station. Values are mean (range) of measured values. HNA: high nucleic acid; bd: below detection

\begin{tabular}{|c|c|c|c|c|c|}
\hline Depth (m) & $\begin{array}{l}\text { Temp. } \\
\left({ }^{\circ} \mathrm{C}\right)\end{array}$ & $\begin{array}{c}\text { Nitrate } \\
(\mu \mathrm{M})\end{array}$ & $\begin{array}{l}\text { Chl } a \\
\left(\mu \mathrm{g} \mathrm{l}^{-1}\right)\end{array}$ & $\begin{array}{c}\text { Heterotrophic } \\
\text { prokaryotes }\left(\times 10^{6} \mathrm{ml}^{-1}\right)\end{array}$ & $\begin{array}{l}\% \text { HNA } \\
\text { cells }\end{array}$ \\
\hline \multicolumn{6}{|l|}{ Shelf } \\
\hline $3-6$ & $13.0(0-15.4)$ & $1.0(0.6-1.5)$ & $5.9(4.30-7.47)$ & $3.2(1.7-4.3)$ & $72(63-79)$ \\
\hline $20-26$ & $11.3(9.0-13.7)$ & $21.2(16.4-26.5)$ & $1.43(0.88-2.01)$ & $1.5(1.1-2.5)$ & $74(69-78)$ \\
\hline $40-48$ & $8.3(8.1-8.5)$ & $27.4(27.3-27.5)$ & $0.75(0.49-0.91)$ & $0.9(0.7-1.1)$ & $75(72-80)$ \\
\hline \multicolumn{6}{|l|}{ Slope } \\
\hline $3-5$ & $14.3(0-16.3)$ & $0.1(0-0.2)$ & $0.63(0.43-0.76)$ & $2.1(1.3-3.1)$ & $51(46-64)$ \\
\hline $10-25$ & $13.4(11.4-16.0)$ & $2.7(0.1-7.3)$ & $1.11(0.62-1.38)$ & $2.4(1.3-4.0)$ & $58(51-63)$ \\
\hline $50-74$ & $8.4(8.2-8.5)$ & $23.0(20.7-25.3)$ & $0.13(0.05-0.17)$ & $0.7(0.6-0.8)$ & $65(61-69)$ \\
\hline \multicolumn{6}{|l|}{ Basin } \\
\hline $3-5$ & $18.6(18.3-19.0)$ & $0.1(0-0.2)$ & $0.25(0.18-0.45)$ & $0.9(0.8-1.0)$ & $56(46-73)$ \\
\hline $40-50$ & $11.7(10.7-13.4)$ & $2.1(0-5.3)$ & $1.53(0.49-2.23)$ & $1.3(0.8-2.6)$ & $61(49-67)$ \\
\hline $200-501$ & $6.2(5.4-7.0)$ & $37.2(34.1-40.0)$ & bd & $0.3(0.2-1.0)$ & $66(56-71)$ \\
\hline
\end{tabular}


the slope and basin stations (1-way ANOVA, p = 0.0003, followed by multiple comparisons with Tukey-Kramer correction).

\section{Cell-specific leucine and thymidine incorporation rates}

For all 9 samples collected at each station, at least 3 replicates of each leucine and thymidine sample were sorted into HNA and LNA cells using flow cytometry. Using side scatter values from the flow cytometer as a proxy for cell size, HNA cells were significantly larger than LNA cells (Student's $t$-test, Bonferroni correction, $\mathrm{p}<<$ 0.0001). Cell-specific leucine and thymidine (Table 2) incorporation rates generally decreased with increasing depth. Mean cell-specific incorporation rates for HNA cells were greater than rates for LNA cells for both leucine and thymidine in most samples (89\% of leucine samples and $85 \%$ of thymidine samples).

Cell-specific leucine incorporation for both HNA and LNA cells, and cell-specific thymidine incorporation for HNA cells were significantly correlated with depth, temperature, salinity and nutrient (nitrate, phosphate and silicate) concentrations (Pearson's r, p-values < 0.05). None of these correlations were significant for cell-specific thymidine incorporation by LNA cells.

The ratio between HNA incorporation and LNA incorporation was significantly higher (Student's $t$-test, Bonferroni post-hoc correction, $\mathrm{p}=0.0017$ ) for leucine (arithmetic mean 2.29, 1.92 to $2.60,95 \%$ confidence intervals) than the ratio for thymidine (arithmetic mean $1.57,1.26$ to $1.88,95 \%$ confidence intervals). The ratio of HNA to LNA thymidine incorporation was significantly negatively correlated with depth (Pearson's $\mathrm{r}=$ $-0.57, \mathrm{p}=0.0025)$; this correlation was not significant for leucine incorporation. By definition, HNA cells have higher green fluorescence than LNA cells, and mean HNA green fluorescence was 3.15 times higher than mean LNA green fluorescence (95\% confidence intervals for all samples: 3.00 to 3.31); no difference in the ratio of HNA:LNA green fluorescence was observed between stations. Variability in HNA or LNA green fluorescence was not significantly correlated to leucine or thymidine incorporation by HNA or LNA cells.

\section{Cell-specific Leu:TdR incorporation ratios}

Leu:TdR incorporation ratios were compared as molar incorporation ratios (pM leucine $\mathrm{h}^{-1}$ :pM thymidine $\mathrm{h}^{-1}$ ) to avoid the assumptions necessary to compare incorporation ratios in carbon units. Leu:TdR ratios were significantly higher for HNA cells than for LNA cells (Student's $t$-test, Bonferroni correction, $\mathrm{p}=$ 0.0069) (Fig. 3). There were no significant differences in HNA or LNA Leu:TdR ratios between stations (1way ANOVA, $p>0.05)$. Leu:TdR ratios for both HNA cells and LNA cells were significantly positively correlated with temperature (Pearson's $r=0.66, p=0.00057$ and $r=0.60, p=0.0027$, for HNA and LNA cells, respectively). There were no significant correlations between HNA or LNA cells' Leu:TdR ratios and their side scatter or green fluorescence. While Leu:TdR ratios for HNA cells were not significantly correlated to chl a concentrations, Leu: TdR ratios for LNA cells were weakly correlated to chl a concentrations (Pearson's $r=0.45, p=0.047$ ). However, the use of chl a as a proxy for biomass is limited due to increases in the amount of chl a per cell with increasing depth in small phytoplankton (Olson et al. 1990) and a relative increase in abundance of smaller cells further from the Oregon coast (Sherr et al. 2005). Therefore, chl a concentrations were also converted to phytoplankton biomass using conversion

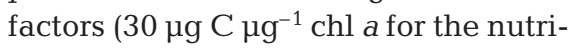
ent-replete shelf station, and $90 \mu \mathrm{g} \mathrm{C}$

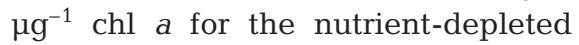
slope and basin stations) from Eppley (1968), which have previously used for 


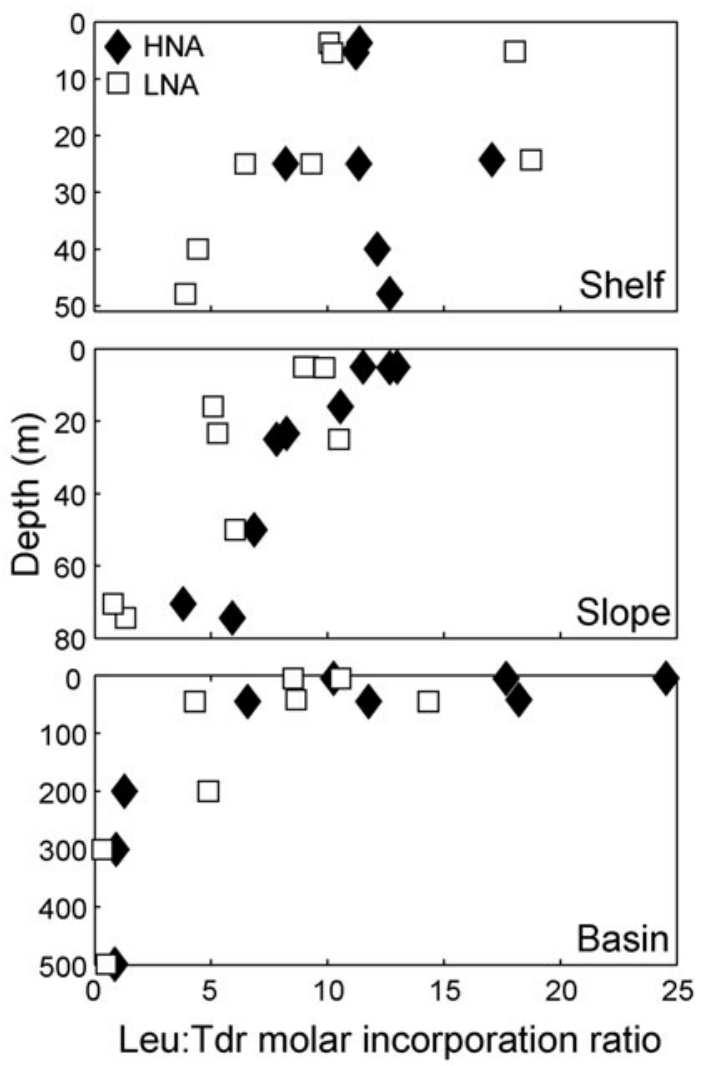

Fig. 3. Ratio of cell-specific leucine incorporation divided by cell-specific thymidine incorporation (Leu:TdR ratio) for HNA and LNA cells plotted against depth for the 3 sampling stations

Oregon coast samples (Sherr et al. 2005). The Leu:TdR ratio for HNA cells was also not significantly correlated to phytoplankton biomass, although the Leu:TdR ratios for LNA cells were still weakly correlated to phytoplankton biomass (Pearson's $\mathrm{r}=0.53, \mathrm{p}=0.02$ ).
II regression, major axis, $95 \%$ confidence intervals for the slope: 0.56 to $1.17,95 \%$ ). Incorporation rates for total thymidine and for whole seawater thymidine were also positively correlated $\left(\log _{10}\right.$-transformed data, Pearson's $r=0.88, \mathrm{p}<<0.0001)$. However, the slope of the line between the sorted and whole seawater thymidine incorporation rates was 0.58 , and the $95 \%$ confidence intervals for the slope did not include 1 (Model II regression, major axis, 95\% confidence intervals for the slope: 0.45 to 0.72 ) because the sorted thymidine incorporation rates were higher than those for whole seawater. To facilitate comparison of total thymidine incorporation rates with existing data, the bias in thymidine incorporation rates in the sorted samples was corrected by plotting the sorted total incorporation rates against whole seawater incorporation rates. The sorted incorporation rates were then adjusted in order to set the intercept of the Model II (major axis) regression line equal to 0 .

Volumetric incorporation rates of leucine and thymidine were significantly correlated to each other for both HNA and LNA cells (Pearson's $r=0.98$ and 0.92, for HNA and LNA cells, respectively, both p-values $<<0.0001$ ). At the shelf station, volumetric incorporation rates of leucine and thymidine for both HNA and LNA populations decreased with increasing depth (Table 3). Conversely, at the slope there was a mid-depth maximum in total leucine and thymidine incorporation by both HNA and LNA populations. The proportion of total leucine and thymidine incorporation attributable to HNA cells was significantly higher at the shelf station than at the slope and basin stations (Fig. 4) (1-way ANOVA, followed by Tukey-Kramer multiple comparison test; $\mathrm{p}=0.0161$ for leucine incorporation and $\mathrm{p}<0.0001$ for thymidine incorporation).

\section{Total incorporation rates}

Total incorporation rates were obtained by multiplying the cell-specific incorporation rate by the abundance of cells in each group. We checked whether cell sorting potentially resulted in underestimation of total leucine or thymidine incorporation rates. The volumetric incorporation rates of sorted total bacteria (HNA + LNA cell regions) were positively correlated to volumetric bacterial leucine incorporation rates of whole seawater $\left(\log _{10}\right.$-transformed data, Pearson's $\mathrm{r}=$ $0.75, \mathrm{p}<<0.001)$. The slope of the line between sorted and whole seawater leucine incorporation was 0.82 (Model
Table 3. Total leucine and thymidine incorporation rates for HNA and LNA cells. Total incorporation rates were obtained by multiplying cell-specific incorporation rates by cell abundances for each sorted group. Data are mean (range); units are $\mathrm{pM}$ isotope incorporated $\mathrm{h}^{-1}$

\begin{tabular}{|lcccc|}
\hline \multirow{2}{*}{ Depth $(\mathrm{m})$} & \multicolumn{2}{c}{ Leu incorporation } & \multicolumn{2}{c|}{ TdR incorporation } \\
& HNA & LNA & HNA & LNA \\
\hline Shelf & & & & \\
$3-6$ & $49.2(24.5-73.0)$ & $6.6(5.3-8.9)$ & $4.4(2.2-6.4)$ & $0.6(0.3-0.9)$ \\
$20-26$ & $12.5(7.0-22.0)$ & $1.9(1.4-3.0)$ & $1.3(0.5-2.7)$ & $0.2(0.1-0.5)$ \\
$40-48$ & $6.0(5.1-7.6)$ & $0.8(0.4-1.2)$ & $0.5(0.4-0.6)$ & $0.1(0.1-0.2)$ \\
Slope & & & & \\
$3-5$ & $11.5(9.4-14.9)$ & $5.5(3.9-6.6)$ & $0.9(0.7-1.1)$ & $0.6(0.4-0.7)$ \\
$10-25$ & $12.4(6.7-20.3)$ & $5.8(2.6-10.1)$ & $1.3(0.8-1.9)$ & $0.8(0.5-1.0)$ \\
$50-74$ & $0.9(0.5-1.5)$ & $0.3(0.1-0.6)$ & $0.2(0.1-0.2)$ & $0.1(0.1-0.1)$ \\
Basin & & & & \\
$3-5$ & $4.4(2.6-5.4)$ & $1.2(0.7-1.8)$ & $0.3(0.2-0.3)$ & $0.1(0.1-0.2)$ \\
$40-50$ & $4.0(2.5-5.4)$ & $1.2(0.7-1.6)$ & $0.3(0.3-0.4)$ & $0.1(0.1-0.2)$ \\
$200-501$ & $0.1(0-0.1)$ & $0(0-0.1)$ & $0(0-0.1)$ & $0(0-0)$ \\
& & & & \\
\hline
\end{tabular}




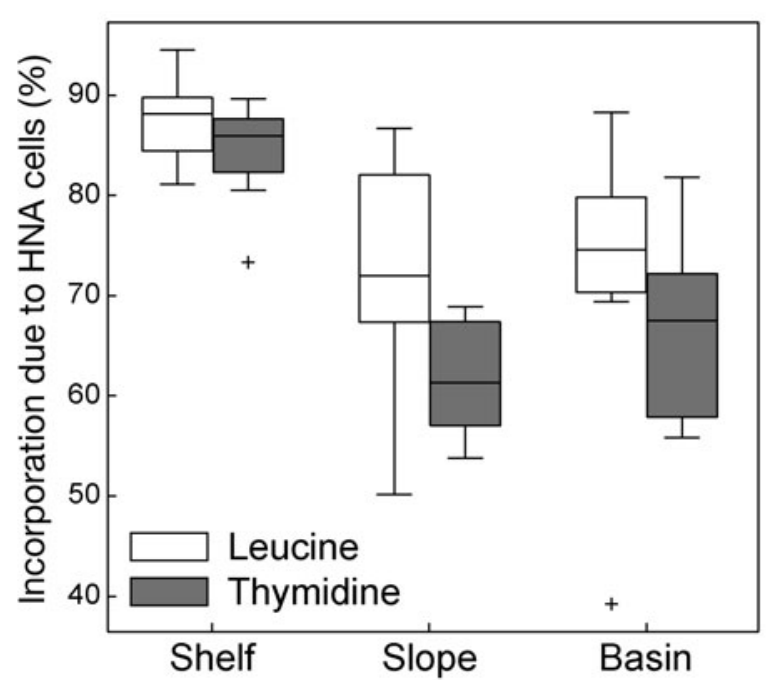

Fig. 4. Percentage of total leucine and thymidine incorporation attributable to HNA cells at the shelf, slope and basin stations. The box represents the middle $50 \%$ of the data, or the inter-quartile range (IQR); whiskers extending above and below the box include data within 1.5 IQRs of the box; +: outliers, defined as percentages of total incorporation between 1.5 and 3 IQRs distant from the box. Lines in boxes: median

Total leucine and thymidine incorporation rates were also converted into biomass-specific incorporation rates by dividing total incorporation rates by side scatter values obtained from the flow cytometer. The low variability in side scatter data relative to the variability in total incorporation rates resulted in little difference between the total incorporation rates and the biomass-specific rates. Therefore, HNA biomassspecific incorporation of leucine and thymidine was higher than LNA biomass-specific incorporation of leucine and thymidine for samples throughout the water column.

\section{DISCUSSION}

Concurrent measurements of leucine and thymidine incorporation have been used to assess variability in the growth state of heterotrophic bacterioplankton (Chin-Leo \& Kirchman 1990, Li et al. 1993, Shiah \& Ducklow 1997, Pomroy \& Joint 1999). This is the first data set in which cell-specific rates of leucine and thymidine incorporation have been compared for HNA and LNA bacterial cells in an open ocean system. Our data from samples collected off the Oregon coast indicated that variability in the growth state of both HNA and LNA cells was more strongly correlated to physical parameters than to phytoplankton stocks. However, the proportional importance of LNA cells to total bacterial activity was higher in regions with lower phytoplankton biomass.

Flow cytometric sorting of HNA and LNA cells did not cause a systematic bias in leucine incorporation rates, as shown by the significant correlation between total leucine incorporation rates and rates obtained from unsorted whole seawater samples. However, while sorted thymidine incorporation rates and those of whole seawater thymidine were significantly correlated, sorted thymidine incorporation rates were systematically higher than rates for unsorted samples. Thus, while trends in thymidine incorporation rates were not affected, the actual sorted total thymidine incorporation rates were higher than those for whole seawater. The cause of the overestimation of thymidine incorporation rates in the sorted samples is not known. To allow comparison with other data sets, the sorted total incorporation rates were shifted such that a plot of sorted total incorporation rates versus whole seawater incorporation rates had a $y$-intercept of zero.

\section{Cell-specific leucine and thymidine incorporation rates}

We compared 2 major metabolic processes, protein synthesis and DNA synthesis, in the present study. HNA cells incorporated both leucine and thymidine at higher cell-specific rates relative to LNA cells, although the proportional difference between HNA and LNA incorporation rates was greater for leucine than for thymidine. The greater discrepancy in leucine incorporation rates between HNA and LNA cells suggested that HNA cells had higher rates of protein synthesis than LNA cells. This supports previous observations that HNA cells tend to be both larger and incorporate more leucine than LNA cells (Bernard et al. 2000, Lebaron et al. 2002). Larger cell size should foster protein synthesis to a greater degree than DNA synthesis, which we observed as smaller differences in DNA synthesis between HNA and LNA cells.

The fact that cell-specific thymidine incorporation rates for LNA cells were significantly greater than background indicated that LNA cells did have measurable rates of DNA synthesis. Thymidine incorporation by LNA cells was not significantly correlated with depth, although there was a significant negative correlation with depth for HNA cells. This resulted in greater differences between HNA and LNA thymidine incorporation in surface waters compared to deep water samples. The low thymidine incorporation rates and lack of significant variability for LNA cells in the water column may represent maintenance levels of thymidine incorporation by bacterial cells with lower nucleic acid content. 


\section{Leu:TdR ratios in HNA and LNA subpopulations of marine bacterioplankton}

By measuring leucine and thymidine incorporation separately for HNA and LNA cells, we found that HNA cells had higher Leu:TdR ratios than LNA cells. In rapidly growing cells, protein is synthesized more rapidly than DNA (Neidhardt et al. 1990); thus higher Leu:TdR ratios in HNA cells reflects higher levels of protein synthesis compared to rates in LNA cells. This supports observations that HNA cells are actively growing members of marine microbial communities (Jellett et al. 1996, Gasol et al. 1999) and have higher cell-specific protein concentrations than LNA cells (Zubkov et al. 2001). However, LNA cells incorporated measurable amounts of both leucine and thymidine, and therefore should be considered as cells with lower cell-specific metabolic activity (Smith \& del Giorgio 2003) rather than inactive or dormant cells ( $\mathrm{Li}$ et al. 1995, Jellett et al. 1996, Gasol et al. 1999). However, the HNA and LNA Leu:TdR ratios measured during the present study were instantaneous in situ ratios and therefore give no indication of how the ratios may shift as the ecosystem changes.

Whether in situ measurements of Leu:TdR ratios can be used to indicate if cells are undergoing balanced or unbalanced growth is not yet known. Incubation experiments have been used to obtain Leu:TdR ratios during exponential increases in cell abundance, yet comparing Leu:TdR ratios obtained from incubation experiments with in situ Leu:TdR ratios is problematic for 2 reasons: First, the diversity of cells in incubation experiments changes over time (Eilers et al. 2000, Fuchs et al. 2000); thus bacterioplankton present at the initial sampling points may not be the same phylotypes of bacterioplankton responsible for variability in Leu:TdR ratios at the end of the incubation. While all broadly defined phylogenetic groups of bacteria are able to incorporate both leucine and thymidine, the proportion of each group actively incorporating leucine or thymidine does vary (Cottrell \& Kirchman 2003). Second, several studies support the idea that marine bacterial cells are not uniformly active; instead, sub-populations of the bacterial assemblage are more or less active at any one time (del Giorgio \& Bouvier 2002, Cottrell \& Kirchman 2003, Smith \& del Giorgio 2003). Thus, the idea of using any particular Leu:TdR ratio as an indicator of balanced growth of the in situ bacterial assemblage is probably invalid, as only a portion of the population may be actively growing during the sampling period. What our data do indicate is that higher Leu:TdR ratios are associated with the more active members of marine bacterioplankton: HNA cells. Increases in the Leu:TdR ratio have been previously observed in a range of aquatic ecosystems, where whole water Leu:TdR ratios increased as measured bacterial activity increased (Servais 1992).

One explanation for higher Leu:TdR ratios by HNA cells could be that the Leu:TdR ratio is primarily a function of cell size. HNA cells were larger than LNA cells and had higher Leu:TdR ratios. However, when the analysis was limited to HNA cells, there was no significant correlation between HNA cells' Leu:TdR ratio and cell size. Bacterial protein content per cell is correlated to cell volume (Simon \& Azam 1989), and protein can comprise more than $50 \%$ of the total dry weight of a bacterial cell (Neidhardt et al. 1990). Therefore, the higher Leu:TdR ratios in HNA cells than LNA cells could be due to the relationship between protein content and cell size, and the lack of a similar relationship between the DNA content and cell size.

Temperature (Tibbles 1996, Shiah \& Ducklow 1997) and substrate supply (Chin-Leo \& Kirchman 1990, Kirchman 1990) both have an effect on in situ Leu:TdR ratios. We used chl a concentration as a proxy for organic carbon substrate supply, and observed no significant correlations between Leu:TdR ratios and chl a concentrations or phytoplankton biomass for HNA cells and only a weak correlation for LNA cells. The presence of higher Leu:TdR ratios at higher water temperatures supports previous observations of positive correlations between temperature and Leu:TdR ratios (Tibbles 1996). A confounding factor in linking Leu:TdR ratios and temperature is spatial variability in temperature between sampling stations. The warmest water temperatures were measured at the surface of the basin station, where the highest Leu:TdR ratios were obtained. Furthermore, during this cruise, biomass-specific, surface, primary production rates (assessed via incorporation of ${ }^{14} \mathrm{C}$-labeled bicarbonate) were highest at the basin station and lower at the shelf station (R. Letelier unpubl. data). Further research will be needed to determine whether the heterotrophic community has higher Leu:TdR ratios in response to higher temperatures or higher biomass-specific carbon fixation rates, or a combination of both factors.

The lack of variability with depth in the Leu:TdR ratio of HNA cells at the shelf station compared to the other 2 stations was striking (Fig. 3). Although cell-specific leucine and thymidine incorporation decreased with increasing depth at the shelf station, the ratio between the 2 rates remained constant, indicating a similar growth state in HNA cells at the shelf station. Using observed correlations between beam attenuation and particulate organic carbon and nitrogen concentrations, Karp-Boss et al. (2004) revealed elevated concentrations of particulate organic matter in the benthic boundary layer at near-shore sampling stations north of our study region. One interesting hypothesis to test is whether this organic matter represents substrate avail- 
able to the heterotrophic community that could be the cause of consistently higher HNA Leu:TdR ratios throughout the water column at the shelf station.

In order to compare the Leu:TdR ratios obtained in the present study with data from other regions of the sea, the molar incorporation rates for leucine and thymidine determined separately for HNA and LNA cells were combined to calculate total bacterial leucine and thymidine incorporation rates. The molar Leu:TdR incorporation ratios obtained in the present study are at the low end of the mean Leu:TdR ratios previously found in marine ecosystems (Table 4), and are lower than mean values obtained from the same region in September 1998, which was an El Niño year (Sherr et al. 2001). However, the minimum Leu:TdR ratios from this study are not lower than the lowest Leu:TdR ratios obtained from the large number of samples ( $\mathrm{n}>3000$, for $500 \mathrm{~m}$ depth) gathered during Joint Global Ocean Flux Study (JGOFS) field programs. Whether our molar Leu:TdR ratios were due to low levels of bacterial production at the end of the upwelling season or some other factor is not clear.

\section{Variability in total incorporation rates across marine ecosystems}

In the present study, total leucine and thymidine incorporation rates were significantly correlated for both HNA and LNA cells. Correlations between leucine and thymidine incorporation have been ob- served in other ecosystems (Chin-Leo \& Kirchman 1988, Servais 1992, Wiebinga et al. 1997, Ducklow et al. 2001a). Decoupling between the 2 rates has been interpreted as unbalanced growth by the prokaryotic community (Chin-Leo \& Kirchman 1990, Torréton \& Dufour 1996, Gasol et al. 1998, Sherr et al. 2001). The correlation between leucine and thymidine incorporation rates by LNA cells in this study was particularly interesting, as it indicated that LNA cells were involved in both DNA and protein production at proportional rates, albeit at lower levels than for HNA cells. We have previously observed that LNA cells were active with respect to leucine incorporation during a cruise in the spring of 2002 in this region (Longnecker et al. 2005).

Sorting of radioactively labeled cells into subpopulations has revealed HNA cells to be responsible for the bulk of leucine incorporation in freshwater and brackish environments, while the role of LNA cells increases in marine ecosystems (Table 5). The shelf samples examined in the present study had leucine incorporation rates comparable to rates obtained from the Bay of Banyuls-sur-Mer at the SOLA station (Service d'Observation du Laboratoire Arago, $42^{\circ} 29^{\prime} 36^{\prime \prime} \mathrm{N}, 3^{\circ} 8^{\prime} 62^{\prime \prime} \mathrm{E}$ ), but were lower than for samples from the Banyuls-surMer harbor (Lebaron et al. 2001). However, even within the same ecosystem, there can be seasonal variability in HNA and LNA leucine incorporation rates. In the Oregon upwelling system we observed lower total leucine incorporation rates in the fall of 2004 (this study) compared to the spring of 2002 (Longnecker et

Table 4. Molar Leu:TdR ratios in different open ocean ecosystems. Leu:TdR ratio below for this study is the sum of the total HNA and LNA leucine incorporation rates divided by the sum of the total HNA and LNA thymidine incorporation rates. Ratios are mean (range). JGOFS: Joint Global Ocean Flux Study data obtained from US JGOFS web site (usjgofs. whoi.edu) and used with permission of the principal investigators listed in the 'Source' column. Isotope concentrations are concentrations of leucine or thymidine used in the incubations

\begin{tabular}{|c|c|c|c|c|c|c|}
\hline \multirow[t]{2}{*}{ Region } & \multirow[t]{2}{*}{$\begin{array}{c}\text { Additional } \\
\text { information }\end{array}$} & \multirow{2}{*}{$\begin{array}{c}\text { Depth } \\
\text { range } \\
\text { (m) }\end{array}$} & \multicolumn{2}{|c|}{$\begin{array}{l}\text { Isotope conc. } \\
\text { (nM) }\end{array}$} & \multirow[t]{2}{*}{$\begin{array}{l}\text { Leu:TdR } \\
\quad \text { ratio }\end{array}$} & \multirow[t]{2}{*}{ Source } \\
\hline & & & Leu & TdR & & \\
\hline \multirow[t]{3}{*}{ Oregon coast } & Shelf & $0-50$ & 40 & 20 & $11.5(8.0-17.3)$ & This study \\
\hline & Slope & $0-80$ & & & $7.9(2.5-11.5)$ & \\
\hline & Basin & $0-500$ & & & $9.1(0.7-18.4)$ & \\
\hline \multirow[t]{3}{*}{ Oregon coast } & Shelf & $0-45$ & 20 & 10 & $19.5(7.6-50.4)$ & $\begin{array}{l}\text { Recalculated from data } \\
\text { in Sherr et al. (2001) }\end{array}$ \\
\hline & Slope & $0-70$ & & & $15.5(6.2-28.6)$ & \\
\hline & Basin & $0-80$ & & & $32.9(4.7-98.9)$ & \\
\hline \multirow[t]{2}{*}{ Arabian Sea } & Sep (end of monsoon) & $\leq 100$ & 10 & 5 & $35(\sim 0-190)$ & Pomroy \& Joint (1999) \\
\hline & Nov/Dec (inter-monsoon) & & & & $20(\sim 0-120)$ & \\
\hline Southern Ocean & Southern Ocean Iron Expt & $\leq 60$ & 20 & 20 & (range 4-11) & Oliver et al. (2004) \\
\hline Mediterranean Sea & & $\leq 100$ & 20 & 10 & $(0-400)$ & Gasol et al. (1998) \\
\hline Arabian Sea & JGOFS & Depths $<500 \mathrm{~m}$ & $10.5-20$ & $10-20$ & $21.8(0.01-728)$ & Azam/Smith/Ducklow \\
\hline Equatorial Pacific & JGOFS & Depths $<500 \mathrm{~m}$ & 10.5 & 10 & $21.5(2.1-112.1)$ & Ducklow/Kirchman \\
\hline Southern Ocean & JGOFS & Depths $<500 \mathrm{~m}$ & 10.5 & 10 & $19.2(0.1-1292)$ & Ducklow \\
\hline $\begin{array}{l}\text { North Atlantic } \\
\text { Bloom Experiment }\end{array}$ & JGOFS & Depths $<500 \mathrm{~m}$ & 10.5 & 5 & $22.5(2.6-116.3)$ & Ducklow \\
\hline
\end{tabular}


Table 5. Summary of incorporation rates obtained by sorting bacterial cells labeled with ${ }^{3} \mathrm{H}$-leucine using flow cytometry. Data from this study are mean (range) of surface samples and do not include samples collected within and below the pycnocline. This study and Servais et al. (2003) obtained total incorporation values by summing HNA and LNA total incorporation rates, total incorporation rates in the other studies were calculated from values obtained by simultaneously sorting HNA and LNA cells. nd: not determined; Tech R.: Tech River; SOLA: Service d'Observation du Laboratoire Arago

\begin{tabular}{|c|c|c|c|c|c|}
\hline \multirow[t]{2}{*}{ Sample type } & \multirow[t]{2}{*}{ Location } & \multicolumn{3}{|c|}{ Leu incorporation $\left(\mathrm{pM} \mathrm{h}^{-1}\right)$} & \multirow[t]{2}{*}{ Source } \\
\hline & & Total & HNA & LNA & \\
\hline Marine & Shelf & $56(30-82)$ & $49(25-73)$ & $7(5-9)$ & This study \\
\hline Marine & Slope & $17(30-82)$ & $12(25-73)$ & $5(5-9)$ & \\
\hline Marine & Basin & $6(4-7)$ & $4(3-5)$ & $1(1-2)$ & \\
\hline Marine & Shelf & $194(76-481)$ & $167(59-455)$ & $22(10-36)$ & Longnecker et al. (2005) \\
\hline Marine & Slope & $106(71-159)$ & $57(2-102)$ & $13(8-16)$ & \\
\hline Marine & Basin & $23(19-29)$ & $14(11-18)$ & $9(9-9)$ & \\
\hline Freshwater & Tech R. & 82 & 65 & 4 & Lebaron et al. (2001) \\
\hline Freshwater & Tech R. & 1523 & 1588 & 5 & \\
\hline Freshwater & Tech R. & 425 & 420 & 7 & \\
\hline Brackish & Leucate Lagoon & 373 & 343 & nd & \\
\hline Marine & Harbor & 429 & 385 & 5 & \\
\hline Marine & SOLA & 43 & 31 & 11 & \\
\hline Marine & SOLA & 59 & 43 & 12 & \\
\hline Marine & Harbor & 524 & 492 & 8 & Lebaron et al. (2002) \\
\hline Freshwater & Tech R. & 972 & 952 & 20 & Servais et al. 2003) \\
\hline Brackish & Canet & 2773 & 2143 & 630 & \\
\hline Marine & Harbor & 322 & 301 & 21 & \\
\hline Marine & Harbor & 238 & 211 & 27 & \\
\hline
\end{tabular}

al. 2005). Whether the relative role of HNA and LNA cells in leucine incorporation varies seasonally in addition to the spatial variability obvious in Table 5 remains to be examined.

As with leucine, thymidine incorporation rates are also generally higher in estuaries (Shiah \& Ducklow 1994, 1995, 1997), coral reef waters (Yoshinaga et al. 1991), and atoll lagoons (Torréton \& Dufour 1996) compared to open ocean systems (Gasol et al. 1998, Pomroy \& Joint 1999, Ducklow et al. 2001a,b). The thymidine incorporation rates obtained in the present study were within the range of values collected within the Oregon upwelling system in September 1998 (Sherr et al. 2001). However, inter-annual variability was observed, as shelf thymidine incorporation rates were higher in 2004, while offshore thymidine incorporation rates were lower in that year. While no other data on thymidine incorporation by HNA and LNA cells are available, the observed variability in total thymidine incorporation rates indicates the possibility of temporal and spatial variability in thymidine incorporation by the HNA and LNA subpopulations of marine bacterioplankton.

Our data can also be examined as biomass-specific incorporation rates rather than total incorporation rates. As we did not use epifluorescence microscopy to size the HNA and LNA populations, we relied on previously reported correlations between side scatter and cell volume (Troussellier et al. 1999). However, exami- nation of the biomass-specific data resulted in the same conclusions as were reached with the total incorporation data. Therefore, unlike Zubkov et al. (2001), we did not find evidence that LNA cells could be more active on a biomass-specific basis. However, side scatter is not always correlated to cell volume (Christensen et al. 1993, Hedal et al. 1994, López-Amorós et al. 1994). A better indication of cell volume would require sorting HNA and LNA cells, and independently determining their cell volume using epifluorescence microscopy.

At the slope and basin stations, the percentage of total leucine and thymidine incorporation attributable to LNA cells more than doubled for both leucine and thymidine. Integrated chl a concentrations at the slope and basin station were also significantly lower than at the shelf station. Thus, in regions with lower chlorophyll standing stocks, the role of HNA cells in heterotrophic bacterial production decreased. Furthermore, the percent of thymidine incorporation by LNA cells increased more than the percent of leucine incorporation. The importance of increased cell division by LNA cells is supported by repeated observations of increased abundances of LNA cells in oligotrophic environments ( $\mathrm{Li}$ et al. 1995, Casotti et al. 2000, Jochem 2001, Vaqué et al. 2001). Thus, while the Leu:TdR ratios were not correlated to chl a concentrations, the proportion of activity attributable to LNA cells did vary with phytoplankton standing stocks. 
Although it would be tempting to attribute differences in the role of LNA cells between regions to changes in the phylogenetic diversity of HNA and LNA cells, previous research has revealed little high-level variability in phylogenetic diversity between these 2 groups across ecosystems within the Oregon upwelling system (Longnecker et al. 2005). However, there could be different strains of bacteria within these higher-level groupings.

\section{CONCLUSIONS}

In the present study, concurrent measurement of cell-specific leucine and thymidine incorporation revealed that HNA cells were in general more active and had higher rates of protein synthesis than LNA cells. Mean total (HNA and LNA) Leu:TdR ratios were lower than average Leu:TdR ratios found in marine ecosystems, but HNA cells had significantly higher Leu:TdR ratios than LNA cells. We found that Leu:TdR ratios were more responsive to water temperature than to substrate supply (phytoplankton stocks). Investigation of causes of temporal variability in Leu:TdR ratios in HNA or LNA cells is an exciting avenue for future research.

Acknowledgements. We thank J. Fleischbein, J. Jennings, and the captain, crew and marine technicians of the RV 'Wecoma' for technical assistance. E. Etherington and K. Landgren assisted with chlorophyll samples. Primary production experiments were funded by NSF OCE-0001300 to R. Letelier. We thank A. Ashe for conducting the primary production experiments and S. Laney for assistance in analysis of the resulting data. Funding from NSF OCE-0240785 to B.F.S. and E.B.S is gratefully acknowledged.

\section{LITERATURE CITED}

Bernard L, Courties C, Servais P, Troussellier M, Petit M, Lebaron P (2000) Relationships among bacterial cell size, productivity, and genetic diversity in aquatic environments using cell sorting and flow cytometry. Microb Ecol 40:148-158

Button DK, Robertson BR (2001) Determination of DNA content of aquatic bacteria by flow cytometry. Appl Environ Microbiol 67:1636-1717

Casotti R, Brunet C, Aronne B, Ribera d'Alcala M (2000) Mesoscale features of phytoplankton and planktonic bacteria in a coastal area as induced by external water masses. Mar Ecol Prog Ser 195:15-27

Chavez FP, Pennington JT, Castro CG, Ryan JP and 6 others (2002) Biological and chemical consequences of the 1997-1998 El Niño in central California waters. Prog Oceanogr 54:205-232

Chin-Leo G, Kirchman DL (1988) Estimating bacterial production in marine waters from the simultaneous incorporation of thymidine and leucine. Appl Environ Microbiol 54:1934-1939
Chin-Leo G, Kirchman DL (1990) Unbalanced growth in natural assemblages of marine bacterioplankton. Mar Ecol Prog Ser 63:1-8

Christensen H, Bakken LR, Olsen RA (1993) Soil bacterial DNA and biovolume profiles measured by flow-cytometry. FEMS Microbiol Lett 102:129-140

Cottrell MT, Kirchman DL (2003) Contribution of major bacterial groups to bacterial biomass production (thymidine and leucine incorporation) in the Delaware estuary. Limnol Oceanogr 48:168-178

del Giorgio PA, Bouvier TC (2002) Linking the physiologic and phylogenetic successions in free-living bacterial communities along an estuarine salinity gradient. Limnol Oceanogr 47:471-486

Ducklow HW (1999) The bacterial component of the oceanic euphotic zone. FEMS Microbiol Ecol 30:1-10

Ducklow H (2000) Bacterial production and biomass in the oceans. In: Kirchman DL (ed) Microbial ecology of the oceans. Wiley-Liss, New York, p 85-120

Ducklow H, Carlson C, Church M, Kirchman D, Smith D, Steward G (2001a) The seasonal development of the bacterioplankton bloom in the Ross Sea, Antarctica, 1994-1997. Deep-Sea Res II 48:4199-4221

Ducklow HW, Smith DC, Campbell L, Landry MR, Quinby HL, Steward GF, Azam F (2001b) Heterotrophic bacterioplankton in the Arabian Sea: basinwide response to yearround high primary productivity. Deep-Sea Res II 48: 1303-1323

Eilers H, Pernthaler J, Amann R (2000) Succession of pelagic marine bacteria during enrichment: a close look at cultivation-induced shifts. Appl Environ Microbiol 66:4634-4640

Eppley RW (1968) An incubation method for estimating the carbon content of phytoplankton in natural samples. Limnol Oceanogr 13:574-582

Ferrari BC, Oregaard G, Sørensen SJ (2004) Recovery of GFPlabeled bacteria for culturing and molecular analysis after cell sorting using a benchtop flow cytometer. Microb Ecol 48:239-245

Fuchs BM, Zubkov MV, Sahm K, Burkill PH, Amann R (2000) Changes in community composition during dilution cultures of marine bacterioplankton as assessed by flow cytometric and molecular biological techniques. Environ Microbiol 2:191-201

Gasol JM, del Giorgio PA (2000) Using flow cytometry for counting natural planktonic bacteria and understanding the structure of planktonic bacterial communities. Sci Mar 64:197-224

Gasol JM, Doval MD, Pinhassi J, Calderón-Paz JI, GuixaBoixareu N, Vaqué D, Pedrós-Alió C (1998) Diel variations in bacterial heterotrophic activity and growth in the northwestern Mediterranean sea. Mar Ecol Prog Ser 164: $107-124$

Gasol JM, Zweifel UL, Peters F, Fuhrman JA, Hagström A (1999) Significance of size and nucleic acid content in heterogeneity as measured by flow cytometry in natural planktonic bacteria. Appl Environ Microbiol 65: 4475-4483

Gordon LI, Jennings JC, Ross AA, Krest JM (1994) A suggested protocol for continuous flow automated analysis of seawater nutrients (phosphate, nitrate, nitrite and silicic acid) in the WOCE hydrographic program and the Joint Global Ocean Fluxes Study. In: WOCE operations manual, WOCE report no 68/91 revision 1, 1994. Woods Hole Oceanographic Institute, Woods Hole, MA

Hedal M, Norland S, Bratback G, Riemann B (1994) Determination of bacterial cell number and cell volume by means of flow cytometry, transmission electron microscopy, and 
epifluorescence microscopy. J Microbiol Methods 20: 255-263

Herndl GJ, Reinthaler T, Teira E, van Aken H, Veth C, Pernthaler A, Pernthaler J (2005) Contribution of Archaea to total prokaryotic production in the deep Atlantic ocean. Appl Environ Microbiol 71:2303-2309

Huyer A, Smith RL, Fleischbein J (2002) The coastal ocean off Oregon and northern California during the 1997-8 El Niño. Prog Oceanogr 54:311-341

Jellett JF, Li WKW, Dickie PM, Boraie A, Kepkay PE (1996) Metabolic activity of bacterioplankton communities assessed by flow cytometry and single carbon substrate utilization. Mar Ecol Prog Ser 136:213-225

Jochem FJ (2001) Morphology and DNA content of bacterioplankton in the northern Gulf of Mexico: analysis by epifluorescence microscopy and flow cytometry. Aquat Microb Ecol 25:179-194

Karp-Boss L, Wheeler PA, Hales B, Covert P (2004) Distributions and variability of particulate organic matter in a coastal upwelling system. J Geophys Res 109:C09010, doi:09010.01029/02003JC002184

Kirchman DL (1990) Limitation of bacterial growth by dissolved organic matter in the subarctic Pacific. Mar Ecol Prog Ser 62:47-54

Kirchman DL (1993) Leucine incorporation as a measure of biomass production by heterotrophic bacteria. In: Kemp PF, Sherr BF, Sherr EB, Cole JJ (eds) Current methods in aquatic microbial ecology. Lewis Publishing, New York, p 509-512

Lebaron P, Servais P, Agogué H, Courties C, Joux F (2001) Does the high nucleic acid content of individual bacterial cells allow us to discriminate between active cells and inactive cells in aquatic systems? Appl Environ Microbiol 67:1775-1782

Lebaron P, Servais P, Baudoux AC, Bourrain M, Courties C, Parthuisot N (2002) Variations of bacterial-specific activity with cell size and nucleic acid content assessed by flow cytometry. Aquat Microb Ecol 28:131-140

Legendre L, Fèvre JL (1995) Microbial food webs and the export of biogenic carbon in oceans. Aquat Microb Ecol 9:69-77

Li WKW (1995) Composition of ultraphytoplankton in the central North Atlantic. Mar Ecol Prog Ser 122:1-8

Li WKW, Dickie PM, Harrison WG, Irwin BD (1993) Biomass and production of bacteria and phytoplankton during the spring bloom in the western North Atlantic ocean. DeepSea Res II 40:307-327

Li WKW, Jellett JF, Dickie PM (1995) DNA distributions in planktonic bacteria stained with TOTO or TO-PRO. Limnol Oceanogr 40:1485-1495

Longnecker K, Sherr BF, Sherr EB (2005) Activity and phylogenetic diversity of high and low nucleic acid content, and ETS-active, bacterial cells in an upwelling ecosystem. Appl Environ Microbiol 71:7737-7749

López-Amorós R, Comas J, Carulla C, Vives-Rego J (1994) Variations in flow cytometric forward scatter signals and cell size in batch cultures of Escherichia coli. FEMS Microbiol Lett 117:225-229

Malmstrom RR, Kiene RP, Kirchman DL (2004) Identification and enumeration of bacteria assimilating dimethylsulfoniopropionate (DMSP) in the North Atlantic and Gulf of Mexico. Limnol Oceanogr 49:597-606

Marie D, Partensky F, Jacquet S, Vaulot D (1997) Enumeration and cell cycle analysis of natural populations of marine picoplankton by flow cytometry using the nucleic acid stain SYBR Green I. Appl Environ Microbiol 63: 186-193
Neidhardt FC, Ingraham JL, Schaechter M (1990) Physiology of the bacterial cell. Sinauer Associates, Sunderland, MA

Oliver JL, Barber RT, W O Smith J, Ducklow HW (2004) The heterotrophic bacterial response during the southern ocean iron experiment (sofex). Limnol Oceanogr 49: $2129-2140$

Olson RJ, Chisholm SW, Zettler ER, Altabet MA, Dusenberry JA (1990) Spatial and temporal distributions of prochlorophyte picoplankton in the North Atlantic ocean. Deep-Sea Res 37:1033-1051

Peterson WT, Keister JE, Feinberg LR (2002) The effects of the 1997-1999 El Niño/La Niña events on the hydrography and zooplankton off the central Oregon coast. Prog Oceanogr 54:381-398

Pomroy A, Joint I (1999) Bacterioplankton activity in the surface waters of the Arabian Sea during and after the 1994 SW monsoon. Deep-Sea Res II 46:767-794

Servais P (1992) Bacterial production measured by ${ }^{3} \mathrm{H}$ thymidine and ${ }^{3} \mathrm{H}$ leucine incorporation in various aquatic ecosystems. Arch Hydrobiol 37:73-81

Servais P, Casamayor EO, Courties C, Catala P, Parthuisot N, Lebaron P (2003) Activity and diversity of bacterial cells with high and low nucleic acid content. Aquat Microb Ecol 33:41-51

Sherr EB, Sherr BF, Cowles TJ (2001) Mesoscale variability in bacterial activity in the Northeast Pacific Ocean off Oregon, USA. Aquat Microb Ecol 25:21-30

Sherr EB, Sherr BF, Wheeler PA (2005) Distribution of coccoid cyanobacteria and small eukaryotic phytoplankton in the upwelling ecosystem off the Oregon coast during 2001 and 2002. Deep-Sea Res II 52:317-330

Shiah FK, Ducklow HW (1994) Temperature and substrate regulation of bacterial abundance, production and specific growth rate in Chesapeake Bay, USA. Mar Ecol Prog Ser 103:297-308

Shiah FK, Ducklow HW (1995) Multiscale variability in bacterioplankton abundance, production, and specific growth rate in a temperate salt-marsh tidal creek. Limnol Oceanogr 40:55-66

Shiah FK, Ducklow HW (1997) Bacterioplankton growth responses to temperature and chlorophyll variations in estuaries measured by thymidine:leucine incorporation ratio. Aquat Microb Ecol 13:151-159

Simon M, Azam F (1989) Protein content and protein synthesis rates of planktonic marine bacteria. Mar Ecol Prog Ser 51:201-213

Smith DC, Azam F (1992) A simple, economical method for measuring bacterial protein synthesis rates in sea water using ${ }^{3} \mathrm{H}$-leucine. Mar Microb Food Webs 6:107-114

Smith EM, del Giorgio PA (2003) Low fractions of active bacteria in natural aquatic communities? Aquat Microb Ecol 31:203-208

Strickland JDH, Parsons TR (1972) A practical handbook of seawater analysis. Fisheries Research Board of Canada, Ottawa

Tibbles BJ (1996) Effects of temperature on the incorporation of leucine and thymidine by bacterioplankton and bacterial isolates. Aquat Microb Ecol 11:239-250

Torréton JP, Dufour P (1996) Bacterioplankton production determined by DNA synthesis, protein synthesis, and frequency of dividing cells in Tuamotu atoll lagoons and surrounding ocean. Microb Ecol 32:185-202

Troussellier M, Courties C, Lebaron P, Servais P (1999) Flow cytometric discrimination of bacterial populations in seawater based on SYTO 13 staining of nucleic acids. FEMS Microbiol Ecol 29:319-330

Vaqué D, Casamayor EO, Gasol JM (2001) Dynamics of whole 
community bacterial production and grazing losses in seawater incubations as related to the changes in the proportions of bacteria with different DNA content. Aquat Microb Ecol 25:163-177

Wiebinga CJ, Veldhuis MJW, De Baar HJW (1997) Abundance and productivity of bacterioplankton in relation to seasonal upwelling in the northwest Indian Ocean. DeepSea Res I 44:451-476

Editorial responsibility: Josep M. Gasol,

Barcelona, Spain
Yoshinaga I, Fukami K, Ishida Y (1991) Comparison of DNA and protein synthesis rates of bacterial assemblages between coral reef waters and pelagic waters in tropical ocean. Mar Ecol Prog Ser 76:167-174

Zubkov MV, Fuchs BM, Burkill PH, Amann R (2001) Comparison of cellular and biomass specific activities of dominant bacterioplankton groups in stratified waters of the Celtic Sea. Appl Environ Microbiol 67:5210-5218

Submitted: December 28, 2005; Accepted: March 21, 2006 Proofs received from author(s): May 19, 2006 